\title{
The Effect of Loose Parts Media on Early Childhood Naturalist Intelligence
}

\author{
Nita Priyanti ${ }^{1}$ \\ Jhoni Warmansyah ${ }^{2}$ \\ Universitas Panca Sakti Bekasi, Indonesial \\ Institut Agama Islam Negeri Batusangkar, Indonesia ${ }^{2}$
}

DOI: https://doi.org/10.21009/JPUD.152.03

Accepted: September 15 ${ }^{\text {th }}$ 2021.Approved: October $4^{\text {th } 2021 . ~ P u b l i s h e d: ~ N o v e m b e r ~} 30^{\text {th }}, 2021$

\begin{abstract}
Naturalist intelligence of early childhood has a very big role in today's modern age as the basis for children to have environmental-loving behaviour. The purpose of this study was to determine the effect of Loose Parts learning media on the naturalist intelligence. This study uses a quasi-experimental method with data collection techniques through multiple intelligence tests of children's intelligence instruments. The subjects of this study were 17 children aged 5-6 years. The results showed that there was a significant effect of giving Loose Parts media to the naturalist intelligence of early childhood after seeing a difference between pre-test and post-test. The use of natural-based Loose Parts media can be a means for teachers to increase children's naturalist intelligence in kindergarten and be a development of conventional media made from manufacturers in the learning cycle so far. For further research, it is recommended to look at the influence of other factors on naturalist intelligence in early childhood.
\end{abstract}

Keywords: Early Childhood, Loose Parts, Naturalist Intelligence

\footnotetext{
${ }^{1}$ Corresponding Author:

Universitas Panca Sakti Bekasi

Email: nitapriyanti@panca-sakti.ac.id
} 


\section{INTRODUCTION}

Every child has intelligence in himself, but every child has a different level of intelligence. Some tend to have high intelligence in certain aspects but low in other aspects (Karwowski et al., 2017). Children's intelligence cannot only be measured by their intellectual intelligence (Siregar, 2018). Children are said to be intelligent if they can show one or two abilities that are their advantages (Rizkia et al., 2020). This is largely determined by the stimulation obtained by children from an early age from the surrounding environment. Intelligence is an important capital for children to navigate life (Hapidin et al., 2020). This is in line with what was conveyed by Kristiawan (2016) which states that in an effort to prepare for human-resource development, it must be done from an early age which is expected to have success in the future.

Learning in early childhood must be able to increase the intelligence of children according to their talents. One of the intelligences that are important to be improved in children is naturalist intelligence. Naturalist intelligence is one of the intelligences possessed by humans in knowing various kinds of fauna, plants, and sensitivity in respecting nature and the environment (Utami et al., 2020). In line with what was expressed by Ningrum, et al., (2018), that naturalist intelligence has a significant impact on environmental awareness, and can develop positive attitudes towards the environment. This is in line with Saripudin's (2017), research which states that naturalist intelligence needs to be improved to foster children's concern for the natural environment so that children will love and protect nature. If naturalist intelligence has been improved from an early age in children, then the natural damage that many studies are currently taking place can be minimized (Juniarti, 2015).

The development of children's naturalist intelligence is not only influenced by heredity but is also influenced by environmental factors that surround the child. The guidance of parents and teachers is very much needed in the child's development period so that the child's naturalist intelligence can develop optimally (Latifah \& Prasetyo, 2019). Hartika, et al., (2019), revealed that there is a positive and significant relationship between naturalist intelligence and environmental attitudes, meaning that the higher the child's naturalist intelligence, the better the child's attitude towards the environment..

Children's naturalist intelligence can be stimulated by applying the most appropriate way, such as introducing the surrounding environment. The problem is, from the initial observations of research in several kindergartens in Pamulang District, it was found that children's natural intelligence was still not developed optimally. This can be seen from the children's low attention to the surrounding environment such as the lack of interest in children participating in planting activities, watering, pulling grass, and cleaning up trash. Another problem seen in the classroom is the lack of media facilities that can free children to learn in a fun way. The reason is teachers are still reluctant to prepare natural materials, design activities to stimulate children's intelligence, and bridge children's freedom of work. Not infrequently, more often teachers provide factory finished goods, such as Lego, blocks, and other popular toys. Of course, this can be a challenge for teachers to be able 
to improve the naturalist intelligence of children by encouraging a child's independence to work with materials that are widely available.

The transition of traditional media to modern technology media raises various problems that previously could not be solved, now have been able to be solved (Rueda et al., 2017). However, this has caused many teachers to be carried away by the flow of technological advances in the world of education. The presence of modern media makes it easier for teachers to be able to solve various problems in the teaching and learning process. When in certain situations, teachers must make their own media creations by leaving modern media, mostly from the teacher's direction to be confused. This is caused by the dependence on the media to be high. Many teachers leave traditional media that can be packaged from natural materials that are easily accessible and obtained and developed, which are widely found around them (Ebrahimi, 2017).

These problems need to be overcome with a treatment given to children to be able to improve naturalist intelligence, one of which is loose part learning media made from natural materials that can be developed into early-childhood learning. Naturalist learning emphasizes direct experience to develop competence so that children can see and understand the environment around them (Liani \& Barsihanor, 2020). There are many ways that can be used to develop and stimulate children's naturalist intelligence, such as involving children in several activities outside the home and school by introducing natural objects around the child, such as playing with kinetic sand (Rocmah, 2016), playing Ludo (Herwati, 2019), Messy Play (Rocmah, 2016), field trip method (Juniarti, 2015), real media (Ramdani, 2017), natural materials (Maulisa et al., 2016), and audiovisual media (Suryani \& Seto, 2020).

Based on several relevant studies that have been described, many studies on increasing naturalist intelligence in early childhood have focused on stimulating their development through various games, methods, materials, and media, but few studies have looked at the effects of using Loose Parts media to increase intelligence early childhood naturalist. If the child's naturalist intelligence development is good, it will be able to help the child's sensitivity to the surrounding environment in his adult age. Therefore, the purpose of this research is to prove the influence of Loose Parts media on naturalist intelligence of early childhood.

\section{THEORITICAL STUDY}

\subsection{Naturalist Intelligence}

According to Armstrong (2002) naturalist intelligence is a person's expertise in recognizing and classifying various species of flora and fauna. In line with this statement, Faridy and Rohendi (2021) naturalist intelligence is an expertise in recognizing and classifying flora and fauna around us, loving various types of plants and animals and connecting species with one another. Naturalist intelligence is the ability possessed by a person in remembering, recognizing, classifying, analyzing or mastering knowledge 
about natural knowledge or the surrounding environments (Anjari \& Purwanta, 2019). Naturalist intelligence will involve the ability to recognize natural forms such as birds, animals, fish, wood, trees and so on (Latifah \& Prasetyo, 2019). Naturalist intelligence will also involve a person's sensitivity in recognizing forms, geological characteristics and even natural structures (Rahmatunnisa \& Halimah, 2018).

Gardner (1994) said that naturalist intelligence was the ability to distinguish and classify what it encounters in the environment. Basically, someone who has a good naturalist intelligence ability will also recognize plants, animals and others that exist in this universe. The characteristic possessed by someone who has naturalist intelligence is that he can recognize order and beauty. That's why naturalist intelligence is often found in people who have high environmental care (Nurhafizah, 2018). This is in line with what was conveyed by Fatonah and Prasetyo (2018), which said that naturalist intelligence was related to how a person recognizes the shape of trees, flowers, animals and other things that exist in nature. This confirms that naturalist intelligence is related to all things related to nature or the surrounding environment. Ningrum et al., (2018) conveyed in their research that naturalist intelligence affects one's awareness of the environment, and naturalist intelligence will affect one's positive attitude towards the environment.

Naturalist intelligence will have a positive influence on the character of caring for the environment in children. If children know naturalist intelligence as early as possible, then children will love the environment, and environmental damage can be minimized. Naturalist development in children is not only influenced by genes, but is also influenced by the environment that exists in the child (Utami et al., 2020). There are many ways to develop children's naturalist intelligence, such as by involving them in activities outside the home and school so that children can find out about natural objects around them. Thus the introduction of the surrounding environment can have a positive impact on joy for children (Anjari \& Purwanta, 2019).

One good source of learning for children is the environment around them, through the environment children can explore what is around them, children can be active and can find new things that come from their environment (Latifah \& Prasetyo, 2019). The environment is one of the most important media to develop children's ability to interact with the surrounding environment (Damayanti et al., 2019). Vardin (2016), in his research also mentions that the environment plays an important role in human development in life.

With the introduction of the environment to children, teachers and parents have indirectly provided a stimulus to the naturalist intelligence of the child, because at this time direct learning in the environment is still rarely found. Because of this, naturalist intelligence in very young children must be improved to support environmental development (Utami et al., 2020). Research conducted Diana et al., (2019) said that naturalist intelligence had a positive relationship with caring for the environment in children, the higher naturalist intelligence in children, the better the child's attitude towards the environment. Therefore, naturalist intelligence in children can be stimulated by introducing the surrounding environment to children. Introduction to the environment 
can start with the introduction of plants around the child, until the child can recognize the characteristics of plants, classify plants, and make children aware of the importance of caring for the environment.

\subsection{Loose Parts Media}

The idea of Loose Parts in the early 1970s, there is little research to support a precise definition of what they are, what they require, and how they are composed (Gull et al., 2019). Houser et al., (2016) argue that Loose Parts is an ambiguous term; however, they share a definition with Nicholson of Loose Parts as various materials, meaning they can be used in more than one way so that children can experiment and create through play. While many Theorists and practitioners have shared their thoughts, ideas, and experiences. A cohesive depiction of the loose play of parts is lacking.

Loose Parts provide opportunities for children to express creativity using materials that can be manipulated, altered, and created through self-guided play. This type of free and active play that is done outdoors allows children to explore on their own what they want to know, demonstrate creativity, and demonstrate understanding of various cognitive, social, and emotional skills (Olsen \& Smith, 2017). Providing opportunities for children to play actively outdoors by being allowed to play in a natural environment will stimulate children's development, children will be healthier and this can increase children's opportunities to take part in independent play in all environments, not only at home or school (Tremblay et al., 2015).

Media loose parts which are free loose materials or objects that are not related to one another (Gibson et al., 2017) and it is an element of STEAM learning (Flannigan \& Dietze, 2018). Our nature is full of loose parts such as twigs, pinecones, shells, stones, leaves, flowers and other natural objects (Swadley, 2021). Parents and educators can collect it from anywhere, at no cost (Wahyuni \& Reswita, 2020). These loose parts not only support children's development, but also help children to connect themselves with their environment (Wardhani et al., 2021).

The Loose Parts component can provide opportunities for children to develop imagination, foster collaboration, and improve cognitive function, facilitating communication and negotiation skills (Gold \& Elicker, 2020). It provide opportunities for children to have unstructured play that is not dominated by adults (Ata-Akturk \& Sevimli-Celik, 2020; Houser et al., 2019). It gives children the freedom to develop their play experience based on their ideas and goals. It also provides a rich environment for play and provides the resources to do what children need to do. Currently, Loose Parts media is strengthening education for the alpha generation (Wahyuni \& Reswita, 2020). The learning approach presented by Steiner Waldorf or Montessori states that real experience is needed by children to acquire life skills. Playing with various Loose Parts helps with these approaches (Aljabreen, 2020; Kirkham \& Kidd, 2017). 


\section{METHOD}

The research method uses a quantitative approach to the type of quasi-experimental method. This method was chosen to see and prove previous research on the effects of loose parts media on children's naturalist intelligence. Quasi-experimental studies were chosen because they do not require a true control group but can include comparison groups (Marsden \& Torgerson, 2012). This method was chosen to see and prove previous research on the effect of rhythmic movements on children's self-regulation. QuasiExperimental Design with pre-test and post-test with the aim of pretest was to ensure comparison of the two groups before treatment; while the post-test allows researchers to determine the direct effect of treatment of the outcome variable (Sugiyono, 2017). The participants were 17 children aged 5-6 years in the Medina Kindergarten, Pamulang District. Collecting data on the child's naturalist intelligence variable using non-test type observations, in the form of observations of children's naturalist intelligence. Data analysis used paired t-test to test the difference between pre-test and post-test. SPSS program is used to identify the results of t-test.

\subsection{Instrument}

The assessment instrument is a modification of the instrument developed by Jamaris (2018). The assessment includes children's naturalist intelligence such as likes doing environmental conservation activities, or caring for plants, animals. Demonstrate good ecological awareness, such as preserving the surrounding environment, sensitive to various natural phenomena, or enjoys observing the nature, such as taking a walk to explore nature in the surrounding environment. Assessment of naturalist intelligence uses a rating scale consisting of 23 indicator items. The range of assessment scores is 1 4 , with a score of 4 for indicators of very good naturalist intelligence and a score of 1 for indicators of naturalist intelligence that still require guidance, where the criteria for student abilities are explained in the rubric.

Table 1. Naturalist Intelligence Instruments

\begin{tabular}{ll}
\hline Aspect & Indicator \\
\hline Environmental & Able to feed and drink pets \\
Conservation & Not afraid of animals, dare to touch and hold animals \\
& Know and able to describe the types of plants \\
& Know and describe their favorite animal \\
& Give fertilizer to plants \\
& Love gardening activities at school \\
& Watering plants \\
Ecological & Know and describe the dangers of garbage \\
Awareness & Throw garbage in its place \\
& Not damage plants in the school environment \\
& Not step on the grass in the school garden \\
& Not scribble on the walls of the classroom \\
& Not disturb animals/animals in the environment inside and outside the \\
& school \\
Sensitivity & Know natural phenomena (earthquakes, volcanic eruptions, etc.) \\
natural phenomena & Take part in emergency simulations \\
& Participate in volcanic eruption experiments \\
& Know the different types of seasons (rainy, dry)
\end{tabular}




\begin{tabular}{ll}
\hline \multirow{2}{*}{$\begin{array}{l}\text { Love } \\
\text { Observation }\end{array}$} & Know the elements of nature (stone, soil, sand, etc.) \\
& $\begin{array}{l}\text { Like / enjoy being outside the classroom or in the school garden } \\
\text { Love to walk around the neighborhood } \\
\text { Like outbound activities/activities } \\
\text { Love to explore objects in the classroom } \\
\text { Enjoy observing objects outside the classroom }\end{array}$ \\
\hline
\end{tabular}

\section{RESULT AND DISCUSSION}

\subsection{Result}

Based on the results of the meaningfulness test using a paired $t$ test sample by fulfilling the testing prerequisites for the hypothesis, it can be explained in table 2.

Table 2. Naturalist Intelligence of Pre-Test and Post-Test

\begin{tabular}{cccc}
\hline No & Students & Pre-Test & $\begin{array}{c}\text { Post- } \\
\text { Test }\end{array}$ \\
\hline $\mathbf{1}$ & RK & 56 & 81 \\
$\mathbf{2}$ & ADL & 62 & 87 \\
$\mathbf{3}$ & BD & 66 & 85 \\
$\mathbf{4}$ & AS & 75 & 86 \\
$\mathbf{5}$ & MY & 80 & 85 \\
$\mathbf{6}$ & RMS & 75 & 88 \\
$\mathbf{7}$ & JW & 78 & 87 \\
$\mathbf{8}$ & FLT & 79 & 89 \\
$\mathbf{9}$ & TB & 72 & 90 \\
$\mathbf{1 0}$ & SS & 68 & 92 \\
$\mathbf{1 1}$ & VO & 75 & 84 \\
$\mathbf{1 2}$ & ASE & 67 & 84 \\
$\mathbf{1 3}$ & RM & 75 & 90 \\
$\mathbf{1 4}$ & NH & 66 & 84 \\
$\mathbf{1 5}$ & RK & 69 & 87 \\
& & & \\
$\mathbf{1 6}$ & NC & 70 & 86 \\
$\mathbf{1 7}$ & SG & 55 & 65 \\
\hline & Total & 1188 & 1450 \\
& Y & 69,88 & 85,29 \\
\hline
\end{tabular}

Paired Sample Statistics in Table 3 shows the descriptive value of each variable in the paired sample. The initial test had a mean score of 69.75 from 17 data. The data distribution (Std. Deviation) obtained is 7,415 with a standard error of 1,798. The Final Test has an average value (mean) of 85.29 from 17 data. The distribution of data (Std. Deviation) obtained 5.892 with a standard error of 1.429 . This shows the final test on the data is higher than the initial test.

Table 3. Paired Samples Statistics

\begin{tabular}{ccccll}
\hline & Mean & N & Std. Deviation & Std. Error Mean \\
\hline Pair 1 & Pre-Test & 69,88 & 17 & 7.415 & 1.798 \\
& Post-Test & 85,29 & 17 & 5.892 & 1.429 \\
\hline
\end{tabular}


Table 4. Paired Samples Correlations

\begin{tabular}{ccccc} 
& & N & Correlation & Sig. \\
\hline Pair 1 & Pre-Test \& Post-Test & 17 & .620 & .008 \\
\hline
\end{tabular}

Table 4 shows the results of the correlation test between the two pre-test variables and the post-test variables. Based on the SPSS output, it is known that the correlation coefficient value is 0.620 with a significance value of 0.008 . Because the value of sig. $0.008<$ from 0.05 probability, it can be said that there is a relationship between the pretest and post-test variables.

Table 5. Paired Sample Test

\begin{tabular}{|c|c|c|c|c|c|c|c|c|c|}
\hline & & \multicolumn{5}{|c|}{ Paired Differences } & $\mathrm{t}$ & $\mathrm{df}$ & $\begin{array}{l}\text { Sig. (2- } \\
\text { tailed) }\end{array}$ \\
\hline & & \multirow[b]{2}{*}{ Mean } & \multirow{2}{*}{$\begin{array}{l}\text { Std. } \\
\text { Deviati } \\
\text { on }\end{array}$} & \multirow{2}{*}{$\begin{array}{l}\text { Std. } \\
\text { Error } \\
\text { Mean }\end{array}$} & \multicolumn{2}{|c|}{$\begin{array}{l}6 \text { Confidence Interval of the } \\
\text { Difference }\end{array}$} & & & \\
\hline & & & & & Lower & Upper & & & \\
\hline $\begin{array}{c}\text { Pair } \\
1\end{array}$ & $\begin{array}{l}\text { Pre-Test } \\
\text { Post-Test }\end{array}$ & $\begin{array}{c}- \\
15.412\end{array}$ & $\begin{array}{l}5.95 \\
9\end{array}$ & $\begin{array}{l}1.4 \\
45\end{array}$ & -18.475 & -12.348 & $10 . \overline{6}$ & 16 & .000 \\
\hline
\end{tabular}

The Paired Samples Test (see table 5) is the main output table that shows the results of the tests carried out. This can be seen from the significance value (2-tailed) in the table. The significance value (2-tailed) of this case sample was $0.000(\mathrm{p}<0.05)$. So, the results of the initial test and post-test experienced a significant (meaningful) change. Based on descriptive statistics, the initial test and the final test prove that the final test is higher. It can be concluded that the use of Loose Parts learning media can increase children's naturalist intelligence. This shows that "Loose Parts learning media" has a positive effect on children's naturalist intelligence.

\subsubsection{Playing Activities with Loose parts Natural Material}

The activity in figure 1, children play using natural materials such as water, ropes, bottles, and other loose part accessories. This activity makes children have naturalist intelligence by understanding that plastic objects cannot be decomposed by the earth. The learning objective of this activity is that children are expected to understand protecting the earth and the ability to recycle.

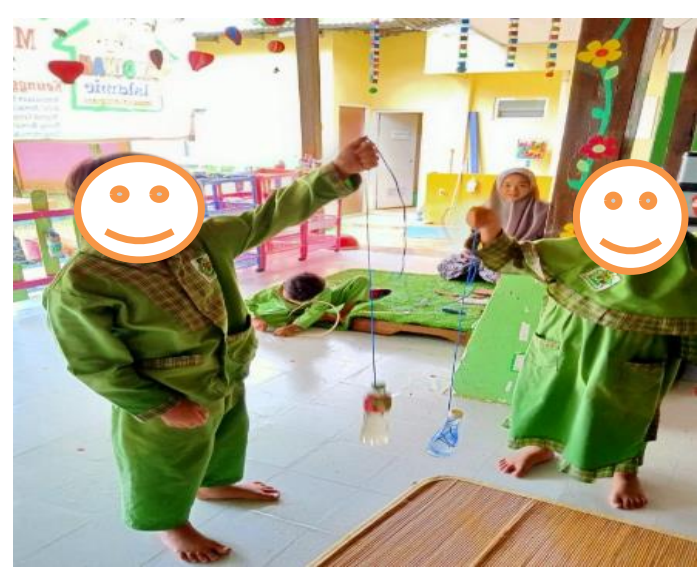

Figure 1. Bottle, Water, and loose part equipment 
In Figure 2, children play using natural materials in the form of seeds. This activity makes children have naturalist intelligence that there are plants that grow from seeds. Grains can be shaped and assembled into various of objects. If cooked, it can become a staple food for humans.

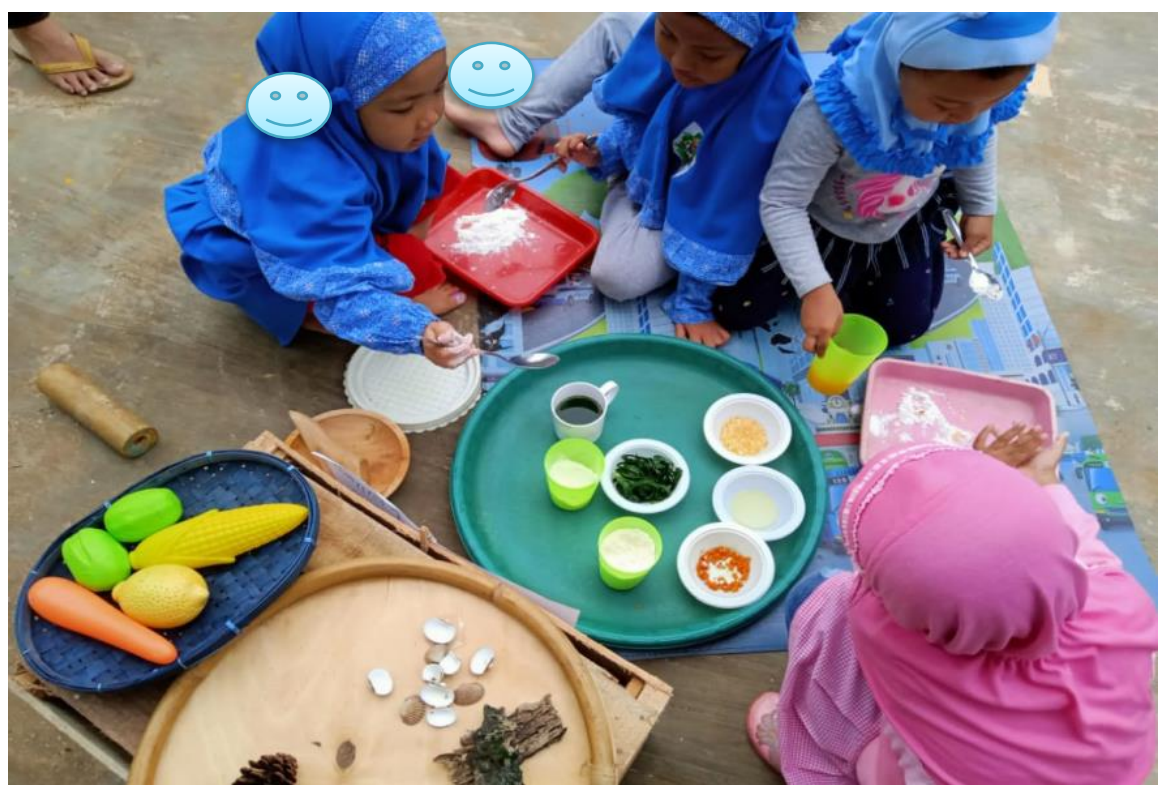

Figure 2. Play using natural materials in the form of seeds

Children's activities in figure 3 and 4, they are playing using various wood materials to develop naturalist intelligence. Children understand wood is a material from nature can be used and arranged into various items are beneficial to humans.

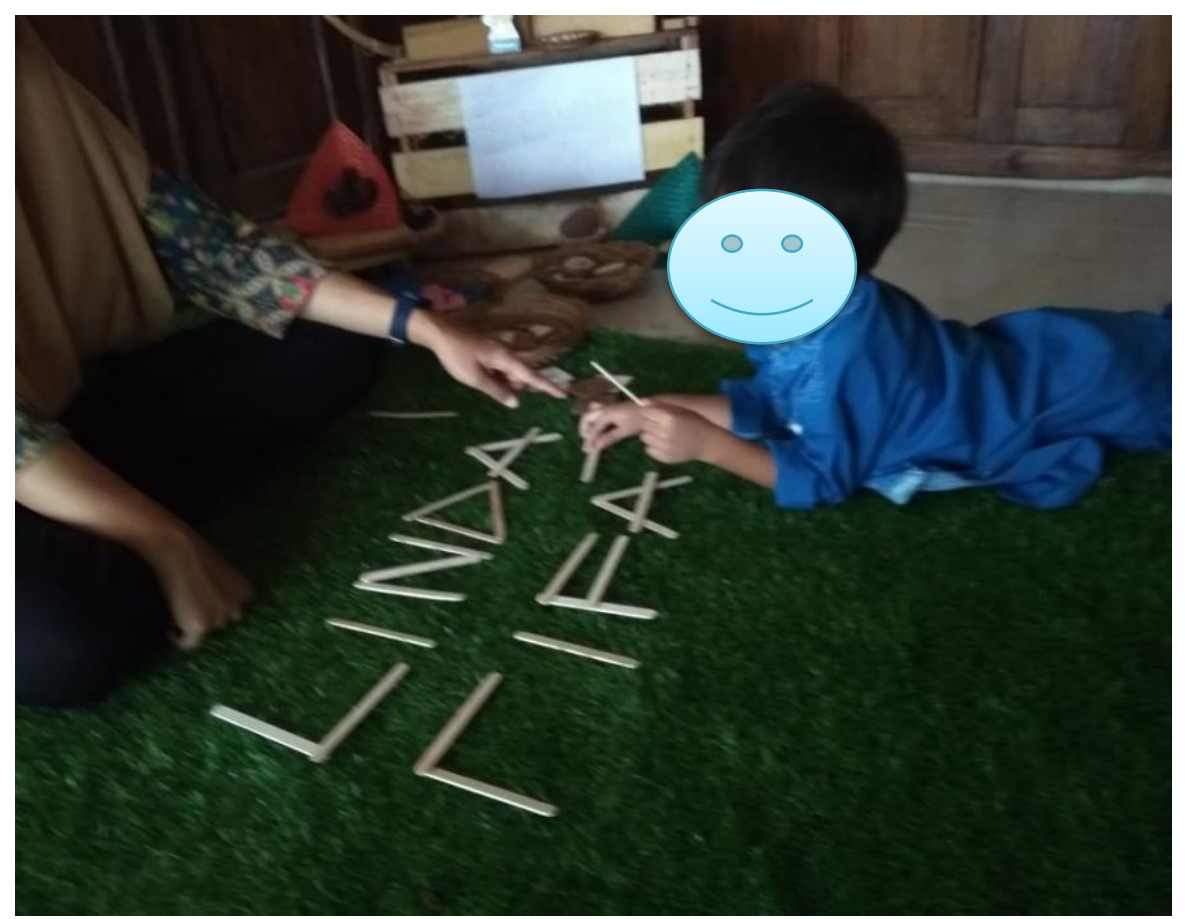

Figure 3. Loose parts made of wood stick 


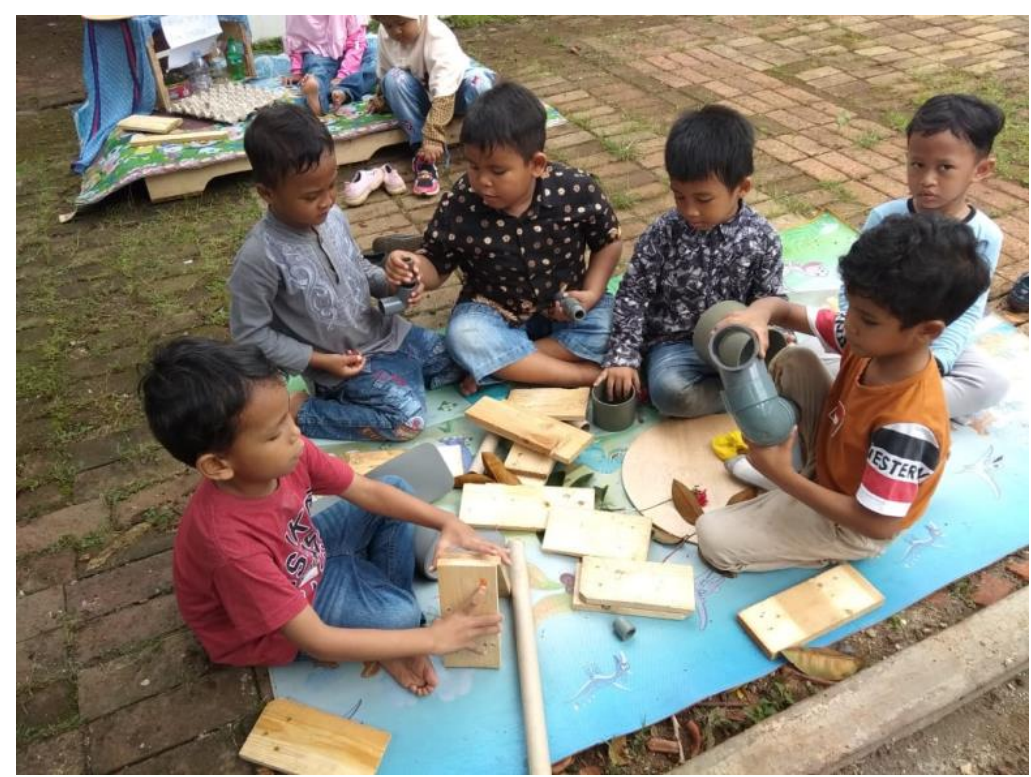

Figure 4. Loose parts made of wood

\subsection{Discussion}

The findings in this study noted that prior to giving stimulation through loose parts media made from natural ingredients, children's naturalist intelligence was quite low; this is related to the learning media in stimulating children's naturalist intelligence, which is still a manufacturer, and less varied so that it is not attractive to children. However, after being given treatment using loose parts media made from natural materials, there was an increase in children's naturalist intelligence. This is also in line with what was conveyed by Sari and Suryana (2019) stating that the use of learning media is a means that can assist teachers in stimulating children's growth and development. Children will learn about various things from the media provided by the teacher.

The second finding in this study was that the post-test results in the provision of loose parts media made from natural materials made children's naturalist intelligence significantly increases. There are many different advantages when using natural materials, because no natural materials are identical to each other (Wahyuningsih et al., 2020). The results of research conducted by Hafizotun (2017) state that children will easily absorb more lessons from natural objects, even they learn to change themselves a little and make adjustments. So, children can learn to accept and understand the differences they see and feel. This will not be obtained from man-made objects such as factory toys. This is supported by the statement delivered by Azizah (2021), which states that children can be designed to learn to love what is given to them. This method will make children learn to love nature from an early age. So that as they grow, they will become individuals who appreciate nature more. So, the use of natural materials is very important in the early-childhood education system.

Similarly, the results found in a study conducted in Europe, Asia and North America showed that children who were involved in using green land for learning had lower levels of stress. This is known from a test through taking samples of their saliva and measuring 
the levels of stress hormones presents. Their stress hormone levels are lower than children who spend their time studying in closed buildings, do not use natural materials and are far from green areas (Keniger et al., 2013). This is also in line with what was conveyed by Flannigan and Dietze (2018), which states that nature is a real educator, and much human knowledge is obtained from nature. Loose parts are one of the learning media that is very relevant to the need for the development of children's naturalist intelligence in PAUD units. It can be used by teachers as a medium to carry out the teaching and learning process. The environment around children can be used as an alternative for teaching and learning activities so that it is hoped that there will be harmony between the learning materials obtained by children and the benefits of the surrounding natural environment.

This is also supported by research conducted Asih and Susanto (2017) which states that when children are accustomed to using natural materials in the learning process, it awakens a sense of peace in them. In addition, there are research results show playing with loose parts media made from natural materials helps the development of children's motor systems improve their skills in writing (Nurfadilah, 2020). Moreover, the diversity of learning absorbed through this method also helps to improve their math skills and vocabulary mastery (Smith-gilman, 2018). This research is also supported by many previous studies, which state that loose parts are media for teaching materials whose usefulness in children's learning is never-ending. Loose part teaching materials can be used as a tool to explore various aspects, problem solving, concentration (Furi et al., 2019), language development (literacy), creativity, fine motor skills, gross motor skills, science, art, logical thinking mathematics, engineering, Technology (Nipriansyah et al., 2021; Prameswari \& Anik Lestariningrum, 2020).

The results of research by Nurjanah (2020) the presence of removable objects, especially natural materials, can free children's creativity, this is due to the principle of using loose parts that can be disassembled and created by children according to their imagination. The results of other studies also state that the use of loose parts as teaching materials invites students to appreciate the materials or objects around them (Imamah \& Muqowim, 2020). In addition, loose parts can provide indirect knowledge to children to protect the environment, because through playing using loose parts media made from natural materials, they get an understanding of recycled materials so that efforts to save the earth in a simple way can be achieved at once (Wardhani et al., 2021). Through loose parts, children also learn about how to implement economic principles in order to understand so that they can resist the urge to not always ask their parents to buy new toys and then easily throw the toys away when they are no longer interesting (Wahyuni \& Reswita, 2020).

\section{CONCLUSION}

The findings of this study indicate that the naturalist intelligence of early childhood can be developed using loose parts made from natural ingredients. Early childhood educators need to realize that learning activities with loose parts media made from natural materials can be used as a means of developing naturalist intelligence for early childhood. The 
results of this study can be used as a reference in the selection of alternative media made from natural materials that can be used in promoting other aspects of development by providing fun learning. The implication of further research is that it is expected to be able to follow up on other factors that can affect naturalist intelligence as part of the development of multiple intelligences possessed by early childhood.

\section{REFERENCES}

Aljabreen, H. (2020). Montessori, Waldorf, and Reggio Emilia: A Comparative Analysis of Alternative Models of Early Childhood Education. International Journal of Early Childhood, 52(3), 337-353. https://doi.org/10.1007/s13158-020-00277-1

Anjari, T. Y., \& Purwanta, E. (2019). Effectiveness of the Application of Discovery Learning to the Naturalist Intelligence of Children About the Natural Environment in Children Aged 5-6 Years. International Conference on Special and Inclusive Education (ICSIE 2018), 296, 356-359. https://doi.org/10.2991/icsie-18.2019.65

Armstrong, T. (2002). You're Smarter Than You Think: A Kid's Guide to Multiple Intelligences. Free Spirit Publishing Inc., 217 Fifth Ave., North, Suite 200, Minneapolis, MN 55401-1299.

Asih, S., \& Susanto, A. (2017). Peningkatan Kecerdasan Naturalis Pada Anak Usia 5-6 Tahun Melalui Model Pembelajaran Di Sentra Bahan Alam. Yaa Bunayya: Jurnal Pendidikan Anak Usia Dini, 1(1). https://doi.org/10.24853/yby.1.1.33-38

Ata-Akturk, A., \& Sevimli-Celik, S. (2020). Creativity in early childhood teacher education: Beliefs and practices. International Journal of Early Years Education, 1-20. https://doi.org/10.1080/09669760.2020.1754174

Azizah, E. N. (2021). Peningkatan Kecerdasan Naturalis Melalui Kolase Bahan Alam Pada Anak Kelompok A TK Kemala Bhayangkari 54 Ngawi. Journal of Childhood Education, 5(1). https://doi.org/10.30736/jce.v5i1.491

Damayanti, A., Akbar, M., \& Yufiarti, Y. (2019). The Interaction Effect of Learning Methods and Naturalist Intelligence Toward Children's Art Creativity. Proceedings of the First International Conference on Technology and Educational Science. https://doi.org/10.4108/eai.21-11-2018.2282278 
Diana, H., Diana, S., \& Wulan, A. R. (2019). Hubungan antara kecerdasan naturalis dengan sikap lingkungan. Konferensi Internasional Tentang Biologi Dan Sains Terapan (ICOBAS).

Ebrahimi, T. (2017). Effect of Technology on Education in Middle East: Traditional Education Versus Digital Education. In Digital Transformation in Journalism and News Media (pp. 519-531). Springer International Publishing. https://doi.org/10.1007/978-3-319-27786-8_38

Faridy, F., \& Rohendi, A. (2021). The Role of Parents in Engaging Early Childhood to Implement 3R (Reduce, Reuse, Recycle). Proceedings of the International Conference on Engineering, Technology and Social Science (ICONETOS 2020), 529(Iconetos 2020), 483-486. https://doi.org/10.2991/assehr.k.210421.070

Fatonah, S., \& Prasetyo, Z. K. (2018). Science Learning Model To Improve Naturalist Intelligence For Early Childhood. Sunan Kalijaga International Journal on Islamic Educational Research, $\quad 1(1), \quad 34-50$. https://doi.org/10.14421/skijier.2017.2017.11-03

Flannigan, C., \& Dietze, B. (2018). Children, Outdoor Play, and Loose Parts. Journal of Childhood Studies, 53-60. https://doi.org/10.18357/jcs.v42i4.18103

Furi, A. Z., Harmawati, Denok, M., \& B.A. (2019). Meningkatkan Kemampuan Kognitif melalui Penerapan Metode Eksperimen Menggunakan Media Loose Parts pada Anak Kelompok B. Emphaty Cons: Journal of Guidance and Counseling, 1(2), $7-19$.

Gardner, H. (1994). Frames Of Mind. New York, NY, Basic Books.

Gibson, J. L., Cornell, M., \& Gill, T. (2017). A Systematic Review of Research into the Impact of Loose Parts Play on Children's Cognitive, Social and Emotional Development. School Mental Health, 9(4), 295-309. https://doi.org/10.1007/s12310-017-9220-9 
Gold, Z. S., \& Elicker, J. (2020). Engineering Peer Play: A New Perspective on Science, Technology, Engineering, and Mathematics (STEM) Early Childhood Education (pp. 61-75). https://doi.org/10.1007/978-3-030-42331-5_5

Gull, C., Bogunovich, J., Goldstein, S. L., \& Rosengarten, T. (2019). Definitions of Loose Parts in Early Childhood Outdoor Classrooms: A Scoping Review Carla Gull Jessica Bogunovich Suzanne Levenson Goldstein Tricia Rosengarten. International Journal of Early Childhood Environmental Education Copyright, 6(3), 37-52.

Hafizotun, L. (2017). Pemberdayaan Sentra Bahan Alam Untuk Mengembangkan Kecerdasan Naturalis Anak Usia Dini Di Taman Kanak-Kanak Islam Terpadu Nurul Ilmi Kota Jambi. Jurnal Al-Ashlah, 1(Vol 1, No 2 (2017)).

Hapidin, Gunarti, W., Pujianti, Y., \& Siti Syarah, E. (2020). STEAM to R-SLAMET Modification: An Integrative Thematic Play Based Learning with R-SLAMETS Content in Early Child-hood Education. JPUD - Jurnal Pendidikan Usia Dini, 14(2), 262-274. https://doi.org/10.21009/JPUD.142.05

Hartika, D., Diana, S., \& Wulan, A. R. (2019). Relationship between naturalist intelligence with environmental attitude. 060017. https://doi.org/10.1063/1.5115717

Herwati, Y. (2019). Pengaruh Permainan Ludo Bergambar Terhadap Kecerdasan Naturalis Anak di Taman Kanak-kanak Tunas Bangsa Bukittinggi. Jurnal Obsesi: Jurnal Pendidikan Anak Usia Dini, 4(1), 428. https://doi.org/10.31004/obsesi.v4i1.358

Houser, N. E., Cawley, J., Kolen, A., Rainham, D., Rehman, L., Turner, J., Kirk, S., \& Stone, M. (2019). A Loose Parts Randomized Controlled Trial to Promote Active Outdoor Play in Preschool-aged Children: Physical Literacy in the Early Years (PLEY) Project. Methods and Protocols, 2(2), 27. https://doi.org/10.3390/mps2020027 
Houser, N. E., Roach, L., Stone, M. R., Turner, J., \& Kirk, S. F. L. (2016). Let the Children Play: Scoping Review on the Implementation and Use of Loose Parts for Promoting Physical Activity Participation. AIMS Public Health, 3(4), 781-799. https://doi.org/10.3934/publichealth.2016.4.781

Imamah, Z., \& Muqowim, M. (2020). Pengembangan kreativitas dan berpikir kritis pada anak usia dini melalui motode pembelajaran berbasis STEAM and loose part. Yinyang: Jurnal Studi Islam Gender Dan Anak, 263-278. https://doi.org/10.24090/yinyang.v15i2.3917

Jamaris, M. (2018). Pengembangan Instrumen Baku Kecerdasan Jamak Anak Usia Dini. PARAMETER: Jurnal Pendidikan Universitas Negeri Jakarta, 25(2), 123-137. https://doi.org/10.21009/parameter.252.08

Juniarti, Y. (2015). Peningkatan Kecerdasan Naturalis Melalui Metode Kunjungan Lapangan (Field Trip). JPUD - Jurnal Pendidikan Usia Dini, 9(2). https://doi.org/10.21009/JPUD.092.05

Karwowski, M., Kaufman, J. C., Lebuda, I., Szumski, G., \& Firkowska-Mankiewicz, A. (2017). Intelligence in childhood and creative achievements in middle-age: The necessary condition approach. Intelligence, 64, 36-44. https://doi.org/10.1016/j.intell.2017.07.001

Keniger, L., Gaston, K., Irvine, K., \& Fuller, R. (2013). What are the Benefits of Interacting with Nature? International Journal of Environmental Research and Public Health, 10(3), 913-935. https://doi.org/10.3390/ijerph10030913

Kirkham, J. A., \& Kidd, E. (2017). The Effect of Steiner, Montessori, and National Curriculum Education Upon Children's Pretence and Creativity. The Journal of Creative Behavior, 51(1), 20-34. https://doi.org/10.1002/jocb.83

Kristiawan, M. (2016). Telaah Revolusi Mental Dan Pendidikan Karakter Dalam Pembentukkan Sumber Daya Manusia Indonesia Yang Pandai Dan Berakhlak Mulia. Ta'dib, 18(1), 13. https://doi.org/10.31958/jt.v18i1.274 
Latifah, C. N., \& Prasetyo, I. (2019). Effectiveness of Educational Game for the Intelligence of Early Childhood Naturalist. Advances in Social Science, Education and Humanities Research, 296(Icsie 2018), 310-314. https://doi.org/10.2991/icsie-18.2019.56

Liani, S., \& Barsihanor. (2020). Strategies for Developing Naturalist Intelligence at Nature Schools. Journal of K6 Education and Management, 3(3), 401-410. https://doi.org/10.11594/jk6em.03.03.12

Marsden, E., \& Torgerson, C. J. (2012). Article in Oxford Review of Education ·. May 2016. https://doi.org/10.2307/41702779

Maulisa, R., Israwati, \& Amri, A. (2016). Meningkatkan Kecerdasan Naturalis Anak Melalui Media Bahan Alam Di Paud It Aneuk Shaleh Ceria Desa Neuheun Kebupaten Aceh Besar. Jurnal Ilmiah Mahasiswa Pendidikan Anak Usia Dini, 1(1), 99-107.

Ningrum, Z. B., Soesilo, T. E. B., \& Herdiansyah, H. (2018). Naturalistic Intelligence and Environmental Awareness among Graduate Students. E3S Web of Conferences, 68, 02004. https://doi.org/10.1051/e3sconf/20186802004

Nipriansyah, N., Rambat Nur Sasongko, Muhammad Kristiawan, E. S., \& Hasanah, P. F. A. (2021). Increase Creativity And Imagination Children Through Learning Science, Technologic, Engineering, Art And Mathematic With Loose Parts Media. Al-Athfaal: Jurnal Ilmiah Pendidikan Anak Usia Dini, 4(1). https://doi.org/10.24042/ajipaud.v4i1.8598

Nurfadilah. (2020). Kemampuan Motorik Halus Melalui Kegiatan Kolase Dengan Bahan Loose Part Pada Anak Usia 4-6 Tahun di Bangkinang Kota. Journal on Teacher Education, 2(1). https://doi.org/10.31004/jote.v2i1.1193

Nurhafizah, N. (2018). Development of Naturalist Intelligence of Children in Kindergarten. International Conference of Early Childhood Education (ICECE 2017), 169, 17-20. https://doi.org/10.2991/icece-17.2018.5 
Nurjanah, N. E. (2020). Pembelajaran STEM Berbasis Loose Parts Untuk Meningkatkan Kreativitas Anak Usia Dini. Jurnal Ilmiah Kajian Ilmu Anak Dan Media Informasi PUD, 1(1), 19-31.

Olsen, H., \& Smith, B. (2017). Sandboxes, loose parts, and playground equipment: A descriptive exploration of outdoor play environments. Early Child Development and $\quad$ Care, $\quad 187(5-6), \quad 1055-1068$. https://doi.org/10.1080/03004430.2017.1282928

Prameswari, T., \& Anik Lestariningrum. (2020). Strategi Pembelajaran Berbasis STEAM Dengan Bermain Loose Parts Untuk Pencapaian Keterampilan 4c Pada Anak Usia 4-5 Tahun. Efektor, 7(1), 24-34. https://doi.org/10.29407/e.v7i2.14387

Rahmatunnisa, S., \& Halimah, S. (2018). Upaya Meningkatkan Kecerdasan Naturalis Anak Usia 4 - 5 Tahun Melalui Bermain Pasir. Jurnal Pendidikan Anak Usia Dini, 2(1), 67-82.

Ramdani, Z. (2017). Increased naturalist intelligence through the use of realia media. Jurnal Golden Age Hamzanwadi University, 1(1), 16-32.

Rizkia, N., Hayati, F., \& Amelia, L. (2020). Analisis Penggunaan Media Pasir Kinetik Dalam Menstimulasi Kecerdasan Naturalis Pada Anak Kelompok B1 Tk Pertiwi Lhoknga. Jurnal Ilmiah Mahasiswa Pendidikan, 1(1), 1-12.

Rocmah, L. I. (2016). Peningkatan Kecerdasan Naturalis Melalui Bermain Messy Play terhadap Anak Usia 5-6 Tahun. PEDAGOGIA: Jurnal Pendidikan, 5(1), 47. https://doi.org/10.21070/pedagogia.v5i1.88

Rueda, L., Benitez, J., \& Braojos, J. (2017). From traditional education technologies to student satisfaction in Management education: A theory of the role of social media applications. Information \& Management, 54(8), 1059-1071. https://doi.org/10.1016/j.im.2017.06.002

Sari, N. E., \& Suryana, D. (2019). Thematic Pop-Up Book as a Learning Media for Early Childhood Language Development. JPUD - Jurnal Pendidikan Usia Dini, 13(1), 43-57. https://doi.org/10.21009/10.21009/JPUD.131.04 
Saripudin, A. (2017). Strategi Pengembangan Kecerdasan Naturalis Pada Anak Usia Dini. AWLADY: Jurnal Pendidikan Anak, 3(1). https://doi.org/10.24235/awlady.v3i1.1394

Siregar, N. M. (2018). Peningkatan Kecerdasan Interpersonal Melalui Aktivitas Fisik Anak Usia 4-5 Tahun. JPUD - Jurnal Pendidikan Usia Dini, 12(2), 291-300. https://doi.org/10.21009/JPUD.122.10

Smith-gilman, S. (2018). The Arts, Loose Parts and Conversations. Journal of the Canadian Association for Curriculum Studies, 16(1), 90-103.

Sugiyono. (2017). Metode Penelitian Bisnis: Pendekatan Kuantitatif, Kualitatif, Kombinasi, dan R\&D. CV. Alfabeta.

Suryani, L., \& Seto, S. B. (2020). Penerapan Media Audio Visual untuk Meningkatan Perilaku Cinta Lingkungan pada Golden Age. Jurnal Obsesi : Jurnal Pendidikan Anak Usia Dini, 5(1), 900-908. https://doi.org/10.31004/obsesi.v5i1.601

Swadley, G. (2021). Any Which Way. . . Loose Parts Play in the Library. Children and Libraries, 19(1), 21. https://doi.org/10.5860/cal.19.1.21

Tremblay, M. S., Gray, C., Babcock, S., Barnes, J., Bradstreet, C. C., Carr, D., Chabot, G., Choquette, L., Chorney, D., Collyer, C., Herrington, S., Janson, K., Janssen, I., Larouche, R., Pickett, W., Power, M., Sandseter, E. B. H., Simon, B., \& Brussoni, M. (2015). Position statement on active outdoor play. International Journal of Environmental Research and Public Health, 12(6), 6475-6505. https://doi.org/10.3390/ijerph120606475

Utami, Rohman, A., \& Islamiyah, R. (2020a). Introduction of the Surrounding Environment to Stimulate Naturalist Intelligence of Early Childhood. Journal of Physics: Conference Series, 1511(1). https://doi.org/10.1088/1742$6596 / 1511 / 1 / 012070$

Vardin, P. A. (2016). Montessori and Gardner's theory of multiple intelligences. Montessori Life, 15(1), 40. 
Wahyuni, S., \& Reswita, R. (2020). Pemahaman Guru mengenai Pendidikan Sosial Finansial pada Anak Usia Dini menggunakan Media Loose Parts. Jurnal Obsesi : Jurnal Pendidikan Anak Usia Dini, 4(2), 962. https://doi.org/10.31004/obsesi.v4i2.493

Wahyuningsih, S., Pudyaningtyas, A. R., Nurjanah, N. E., Dewi, N. K., Hafidah, R., Syamsuddin, M. M., \& Sholeha, V. (2020). The Utilization of Loose Parts Media in Steam Learning for Early Childhood. Early Childhood Education and Development Journal, 2(2), 1. https://doi.org/10.20961/ecedj.v2i2.46326

Wardhani, W. D. L., Misyana, M., Atniati, I., \& Septiani, N. (2021). Stimulasi Perilaku Sosial Anak Usia Dini melalui Media Loose Parts (Bahan Lepasan). Jurnal Obsesi: Jurnal Pendidikan Anak Usia Dini, 5(2), 1894-1904. https://doi.org/10.31004/obsesi.v5i2.694 